Chapter 3

COMPARATIVE CELL RESPONSE TO ARTIFICIAL EXTRACELLULAR MATRIX PROTEINS CONTAINING THE RGD AND CS5 CELL-BINDING DOMAINS

\title{
3.1 Abstract
}

This study addresses endothelial cell adhesion and spreading on a family of artificial extracellular matrix (aECM) proteins designed for application in small-diameter vascular grafts. The aECM proteins contain domains derived from elastin and from fibronectin. aECM 1 contains the RGD sequence from the tenth type III domain of fibronectin; aECM 3 contains the fibronectin CS5 cell-binding domain. Negative control proteins aECM 2 and $\mathbf{4}$ are scrambled versions of aECM $\mathbf{1}$ and 3 , respectively. Competitive peptide inhibition studies and comparisons of positive and negative control proteins confirm that adhesion of HUVECs to aECM proteins $\mathbf{1}$ and $\mathbf{3}$ is sequence specific. When subjected to a normal detachment force of $780 \mathrm{pN}, 3$-fold more HUVEC remained adherent to aECM 1 than to aECM 3. HUVEC also spread more rapidly on aECM 1 than on aECM 3. These results (i) indicate that cellular responses to aECM proteins can be modulated through choice of cell-binding domain, and (ii) recommend the RGD sequence for applications that require rapid endothelial cell spreading and matrix adhesion.

Reproduced with permission from Liu JC, Heilshorn SC, Tirrell DA. Biomacromolecules 2004, 5, 497-504. Copyright 2004 American Chemical Society. 


\subsection{Introduction}

Cardiovascular disease afflicts more than 61 million Americans ${ }^{1}$ and causes 4 million deaths each year in Europe. ${ }^{2}$ Severe atherosclerosis often requires surgical removal of the affected tissue and implantation of an autologous or synthetic vascular graft. The most widely used materials in synthetic vascular grafts are poly(ethylene terephthalate) (PET) and expanded poly(tetrafluoroethylene) (ePTFE); when used in small-diameter grafts, both materials are characterized by high failure rates due to thrombosis and intimal hyperplasia. ${ }^{3-5}$ Autologous saphenous vein yields higher patency rates than synthetic materials, particularly when used to reconstruct the infrapopliteal artery, ${ }^{6,7}$ but autologous vein is limited in supply and patients often suffer from coexisting disease that makes these vessels unsuitable as grafts. ${ }^{5,8}$

A family of artificial proteins that exhibits some of the essential characteristics of the extracellular matrix has been developed for application in small-diameter vascular grafts. ${ }^{9-13}$ Artificial matrices that incorporate functional protein domains have been produced for a variety of applications. ${ }^{14-17}$ The artificial extracellular matrix (aECM) proteins in this study consist of domains derived from elastin and fibronectin (Figure 3.1). The elastin-based repeats are designed to yield the needed mechanical properties while cell-binding domains from fibronectin are incorporated to support the growth of an endothelial monolayer. Urry and coworkers have investigated the physical properties of related elastin-based polymers, ${ }^{18,19}$ demonstrated their biocompatibility, ${ }^{16,20}$ and shown that the GRGDSP cell adhesion sequence in synthetic elastomeric matrixes increases cell adhesion. $^{21}$ 


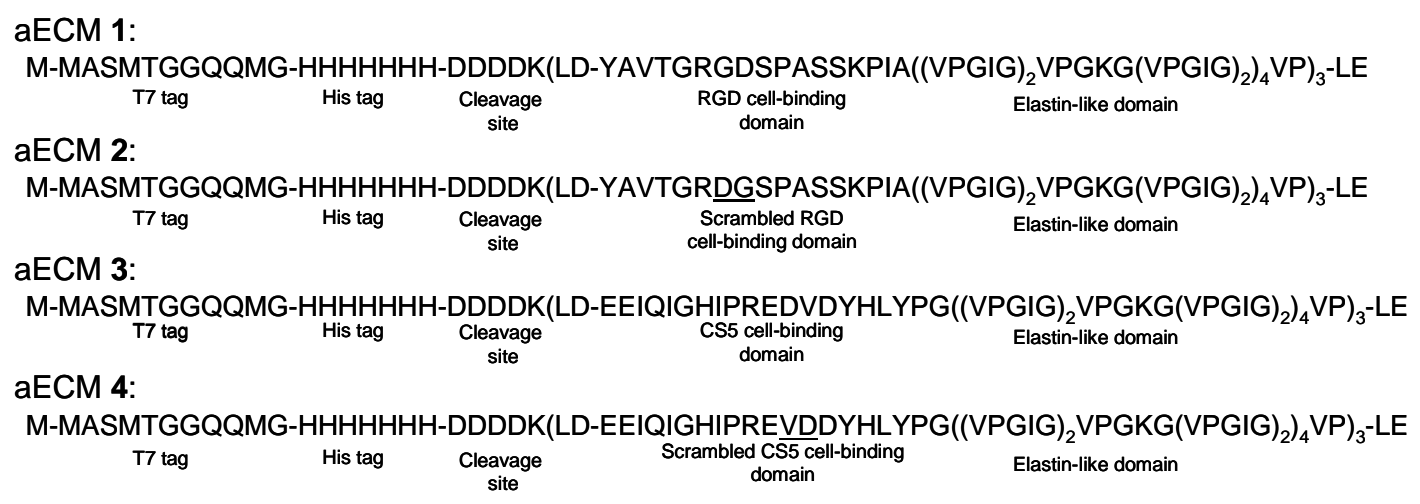

Figure 3.1 Amino acid sequences of aECM proteins 1-4. Each protein contains a T7 tag, a heptahistidine tag, an enterokinase cleavage site, and elastin-like domains containing lysine residues for crosslinking. The RGD cell-binding domain is found in aECM $\mathbf{1}$, whereas the minimal recognition sequence in the RGD cell-binding domain has been scrambled in aECM 2 to provide a negative control. aECM 3 includes the CS5 cell-binding domain whereas aECM 4, the negative control, contains a scrambled version of the CS5 cell-binding domain.

An important criterion in the design of aECM proteins is the tensile modulus; compliance mismatch between the graft and tissue has been strongly implicated in graft failure. It is believed that flow patterns caused by disparities in mechanical properties contribute to intimal hyperplasia ${ }^{22-25}$ and thrombosis. ${ }^{26}$ In attempts to address these issues, several laboratories have developed compliant polyurethane composites. ${ }^{27-29}$ In the approach presented here, we focus on elastin, which forms a crosslinked network in the arterial wall ${ }^{30}$ and which, along with collagen, imparts elasticity and resiliency to the 
vessel. By crosslinking at reactive residues interspersed within the elastin-like domains, the modulus of a crosslinked, free-standing aECM film can be tuned into the range characteristic of elastins $(0.3-0.6 \mathrm{MPa}){ }^{31}$ The extent of crosslinking can be varied to control the compliance..$^{10,11,13}$

A second cause of graft failure is the absence of a confluent endothelial monolayer. Endothelial cells play an important role in maintaining homeostasis of the vasculature. They secrete anticoagulants and procoagulants; control the trafficking of leukocytes, platelets, and red blood cells; and regulate the growth and migration of smooth muscle cells. ${ }^{32-34}$ Deutsch and coworkers found that pre-seeding ePTFE grafts with endothelial cells resulted in a $65 \%$ patency rate after nine years, versus $16 \%$ for nonendothelialized grafts. ${ }^{35}$ Collagen, ${ }^{36}$ fibronectin, ${ }^{37}$ laminin, ${ }^{38}$ gelatin, ${ }^{38}$ pre-clotted blood, ${ }^{39}$ RGD peptides, ${ }^{37}$ and lectins ${ }^{40}$ have all been used as coatings to enhance cell retention in synthetic grafts. To promote endothelialization of grafts derived from aECM proteins, cell-binding domains have been incorporated at regular intervals. In this work, aECM 1 contains the RGD sequence derived from the tenth type III domain of fibronectin; ${ }^{41-43}$ this sequence serves as a ligand for the $\alpha_{\mathrm{v}} \beta_{3}$ and $\alpha_{5} \beta_{1}$ integrins. ${ }^{44,45}$ aECM 2 is a negative control for aECM 1, in which the sequence of the RGD cellbinding domain has been scrambled. aECM 3 has been previously characterized ${ }^{12}$ and contains the CS5 cell-binding domain from the alternatively spliced type III connecting segment of fibronectin. ${ }^{46,47}$ The CS5 cell-binding domain is recognized by the $\alpha_{4} \beta_{1}$ integrin. ${ }^{48}$ When the peptide GREDVY, which includes the minimal binding sequence from the CS5 cell-binding domain, was immobilized on glass surfaces, endothelial cells adhered while fibroblasts, vascular smooth muscle cells, and human blood platelets did 
not. ${ }^{49}$ The CS5 cell-binding domain has been scrambled in aECM 4 to provide a negative control for aECM 3. The goal of this study is to compare cell adhesion and spreading on aECM proteins containing the RGD and CS5 cell-binding domains.

\subsection{Materials and Methods}

\subsubsection{Protein Expression and Purification}

Standard methods for cloning, bacterial growth, protein expression, sodium dodecyl sulfate-polyacrylamide gel electrophoresis (SDS-PAGE), and Western blotting were performed to produce $\mathbf{1}$ and $\mathbf{2}^{50,51}$ The genes for $\mathbf{1}$ and $\mathbf{2}$ were placed under control of a T7 bacteriophage promoter in the pET28 expression vector (Novagen, Madison, WI) and transformed into the protein expression host, BL21(DE3)pLysS (Novagen). Protein expression was performed as described previously ${ }^{11}$ except that cells were harvested 1.52 hours after induction with isopropyl-1- $\beta$-D-thiogalactosidase (IPTG, Calbiochem, Inc., San Diego, CA). The wet cell mass averaged $230 \mathrm{~g}$ per $10 \mathrm{~L}$ fermentation for 1 and 2. The cells were resuspended in TEN buffer (10 mM Tris-HCl, pH 7.5, 1 mM EDTA, 100 $\mathrm{mM} \mathrm{NaCl}$ ) at a concentration of $0.5 \mathrm{~g} / \mathrm{mL}$ and frozen at $-20{ }^{\circ} \mathrm{C}$. The cells were defrosted at $4{ }^{\circ} \mathrm{C}$ with $10 \mu \mathrm{g} / \mathrm{mL}$ of deoxyribonuclease I (Sigma, St. Louis, MO), $10 \mu \mathrm{g} / \mathrm{mL}$ of ribonuclease A (Sigma), and $50 \mu \mathrm{g} / \mathrm{mL}$ of phenylmethylsulfonyl fluoride (Sigma). Water was added to bring the total volume of the solution to $1.3 \mathrm{~L}$. Because the lower critical solution temperature (LCST) of $\mathbf{1}$ is $35^{\circ} \mathrm{C}(10 \mathrm{mg} / \mathrm{mL}$ in PBS, pH 7.3), proteins $\mathbf{1}$ and $\mathbf{2}$ were readily purified via a series of three temperature cycles. The $\mathrm{pH}$ of the solution was 
adjusted to 9 and the solution was centrifuged $\left(39,750 \mathrm{~g}, 2 \mathrm{~h}, 4{ }^{\circ} \mathrm{C}\right)$. The resulting supernatant was adjusted to $1 \mathrm{M} \mathrm{NaCl}$ at $4{ }^{\circ} \mathrm{C}$, warmed to $37{ }^{\circ} \mathrm{C}$, and centrifuged $\left(39,750 \mathrm{~g}, 2 \mathrm{~h}, 37^{\circ} \mathrm{C}\right)$. The pellet was then redispersed in water at a concentration of 100 $\mathrm{mg} / \mathrm{mL}$. This process was repeated twice. The solution was dialyzed at $4{ }^{\circ} \mathrm{C}$ for 3 days and lyophilized. The purity and molecular weights of the proteins were verified by SDSPAGE gels, Western blots, amino acid analysis, and matrix-assisted laser desorption ionization-mass spectrometry (MALDI-MS). Average yields were $580 \mathrm{mg}$ of protein per $10 \mathrm{~L}$ fermentation for $\mathbf{1}$ and $\mathbf{2}$. The expression and purification of $\mathbf{3}$ and $\mathbf{4}$ were similar and have been reported previously. ${ }^{11,12}$

\subsubsection{Cell Culture}

Human umbilical vein endothelial cells (HUVECs) (BioWhittaker, Inc., Walkersville, MD) were maintained in a $37{ }^{\circ} \mathrm{C}, 5 \% \mathrm{CO}_{2}$ humidified environmental chamber. The cells were grown in Endothelial Growth Medium-2 (EGM-2, 2\% serum, BioWhittaker), which was replaced every 2 days. Near confluent HUVEC cultures were passaged non-enzymatically by treatment with $0.61 \mathrm{mM}$ EDTA (Gibco, Grand Island, NY). Passages 2-10 were used; no differences in cell behavior due to passage number were observed.

\subsubsection{Surface Preparation}

Solutions of 1-4 in PBS (1 mg/mL) were adsorbed onto tissue culture polystyrene at $4{ }^{\circ} \mathrm{C}$ overnight. A fibronectin solution $(10 \mu \mathrm{g} / \mathrm{mL})$ was adsorbed under similar conditions. The surfaces were rinsed with PBS, blocked with a $0.2 \%$ solution of heat- 
inactivated bovine serum albumin (BSA, fraction $\mathrm{V}$, Sigma) for $30 \mathrm{~min}$ at room temperature, and rinsed with PBS. To ensure that surfaces coated with aECM 1-4 presented similar numbers of cell-binding domains, protein adsorption was quantified by using a modified protocol for the QuantiPro BCA Assay Kit (Sigma). aECM 1 presented $(4.6 \pm 0.6) \times 10^{11}$ cell-binding domains per well; aECM 3 had $(4.3 \pm 0.6) \times 10^{11}$ cellbinding domains per well. Three independent experiments in triplicate were performed.

Cell viability on adsorbed aECM proteins was measured by monitoring the cleavage of WST-1 (Boehringer Mannheim, Mannheim, Germany). Three independent experiments in triplicate demonstrated that up to $6 \mathrm{~h}$, there were no differences in viability between cells grown on 1-4 and those grown on fibronectin in basal medium.

\subsubsection{Peptide Inhibition}

A colorimetric binding assay described in previous studies was used to examine inhibition of cell adhesion by soluble peptides. ${ }^{12}$ Briefly, the wells of a 96-well plate were prepared as described above and $4 \times 10^{5}$ HUVEC in serum-free EBM- 2 were added to each well. A solution of the peptide [GRGDSP (Calbiochem), GRDGSP (Biopolymer Synthesis and Analysis Facility, California Institute of Technology, Pasadena, CA), GREDVDY (Commonwealth Biotechnologies, Inc., Richmond, VA), or GREVDDY (Commonwealth Biotechnologies, Inc.)] in EBM-2 was added. After 30 min of incubation at $37{ }^{\circ} \mathrm{C}$ and $5 \% \mathrm{CO}_{2}$, nonadherent cells were removed by inversion of the plate and rinsing with PBS. Cells were fixed with $70 \%$ ethanol, stained with $0.1 \%$ crystal violet (Sigma), and thoroughly rinsed with water. The dye was solubilized with a $0.2 \%$ Triton X-100 (Sigma) solution. The absorbance was measured at $595 \mathrm{~nm}$ on a Molecular 
Devices SPECTRAmax Plus ${ }^{384}$ microplate spectrophotometer (Sunnyvale, CA). At least three independent experiments were carried out in triplicate.

\subsubsection{Cell Adhesion}

Cell adhesion experiments were adapted from a previously described method. ${ }^{52}$ Detached HUVECs were labeled with a $5 \mu \mathrm{M}$ solution of calcein acetoxymethyl ester (Molecular Probes, Eugene, OR) in serum-free EBM-2 at room temperature for $30 \mathrm{~min}$. The cells were rinsed with and resuspended in $\mathrm{PBS}^{+}$(PBS containing $1.8 \mathrm{mM} \mathrm{CaCl}_{2}$ and $\left.10 \mathrm{mM} \mathrm{MgSO}_{4}\right)$. After the cells were counted, $0.15 \mathrm{~mL}$ of a cell suspension $\left(2.67 \times 10^{5}\right.$ cells $/ \mathrm{mL}$ in $\mathrm{PBS}^{+}$) was added to each well of a 96-well plate and incubated for $30 \mathrm{~min}$ at $37{ }^{\circ} \mathrm{C}$ and $5 \% \mathrm{CO}_{2}$. Each well was filled with $0.2 \mathrm{~mL}$ of a solution of Percoll (Sigma, $21 \% \mathrm{w} / \mathrm{w}$ in PBS). The plates were centrifuged for $10 \mathrm{~min}$ at $1,100,1000,2000$, or 3000g. The nonadherent cells were wicked away using a harvesting frame (Molecular Devices) with the filters removed. PBS was added to each well, and a fluorescence reading was taken on a Perkin-Elmer HTS 7000 Bio Assay Reader (Wellesley, MA) at an excitation wavelength of $485 \mathrm{~nm}$ and an emission wavelength of $538 \mathrm{~nm}$.

The fluorescence measured in this way is linearly proportional to cell number in a given labeling experiment (data not shown). However, because the amount of dye taken up by each cell varies from experiment to experiment, the fluorescence readings could not be used to determine absolute cell numbers. Instead, a cell adhesion index (CAI) was defined as the fluorescence reading of the test well divided by the fluorescence reading of HUVECs attached to fibronectin subjected to a force of $1 \mathrm{~g}$. Error bars represent the 
standard deviations of three or more independent experiments, each of which evaluated cell adhesion in 6 wells.

To estimate the force applied to each cell, Archimedes' theorem was employed: $F$ $=\left(\rho_{\mathrm{c}}-\rho_{\mathrm{m}}\right) V_{c} \mathrm{RCF}$, where $F$ is the force, $\rho_{c}$ is the density of the cell $(\sim 1.07 \mathrm{~g} / \mathrm{mL}),{ }^{53} \rho_{m}$ is

the density of the medium $(1.123 \mathrm{~g} / \mathrm{mL}),{ }^{52} V_{c}$ is the volume of the cell $(\sim 0.5 \mathrm{pL}),{ }^{53}$ and $\mathrm{RCF}$ is the relative centrifugal force. Estimated normal detachment forces ranged from 26 to $780 \mathrm{pN}$.

\subsubsection{Cell Spreading}

HUVECs in serum-free EBM-2 were added to each well of a 6-well plate at a concentration of $4.8 \times 10^{5}$ cells per well. At 15 min intervals, the plates were removed from the environmental chamber and cells were imaged using a $10 \times$ phase contrast objective on a Nikon Eclipse TE 300 inverted microscope (Tokyo, Japan). Images were captured on a Sony CCD color video camera (model DXC-151A, Tokyo, Japan) equipped with Studio DC10 Plus software, v. 1.06.4 (Pinnacle Systems, Mountain View, CA) and were density-sliced to determine the number of spread (i.e., dark) versus nonspread (i.e., bright and refractive) cells using Scion Image for Windows, release beta 4.0.2 (Scion Corporation, Frederick, MD). Three independent experiments were performed.

\subsubsection{Immunofluorescence Microscopy}

Cells in serum-free EBM-2 were added to an 8-well Lab-Tek II Chamber Slide (Nalge Nunc International, Rochester, NY) at a density of $3 \times 10^{5}$ cells per well and 
grown for $4 \mathrm{~h}$ at $37{ }^{\circ} \mathrm{C}$ and $5 \% \mathrm{CO}_{2}$. The cells were rinsed twice with warm PBS, fixed with ice-cold acetone for $1 \mathrm{~min}$, and rinsed twice with PBS. Cells were blocked with a $10 \%$ BSA solution for $30 \mathrm{~min}$ and then rinsed twice with PBS. The primary antibody solution was incubated in the well for $1 \mathrm{~h}$ at room temperature. All primary antibodies were obtained from Chemicon International, Inc. (Temecula, CA). Antibody clones LM609, JBS5, and V284 were used to detect $\alpha_{\mathrm{v}} \beta_{3}, \alpha_{5} \beta_{1}$, and vinculin at dilutions of 1:80, 1:40, and 1:80, respectively. The wells were then rinsed three times with PBS. The secondary antibody solution contained 0.76 units $/ \mathrm{mL}$ of rhodamine-phalloidin (Molecular Probes), 3\% BSA, and a $\mathrm{Cy} 2$ conjugated affinity-purified goat anti-mouse secondary antibody (Chemicon) (at concentrations of $12.5,6.25$, and $12.5 \mu \mathrm{g} / \mathrm{mL}$ for the anti- $\alpha_{v} \beta_{3}$, $-\alpha_{5} \beta_{1}$, and -vinculin antibodies, respectively). The wells were thoroughly rinsed with PBS and incubated for $5 \mathrm{~min}$ at room temperature in the dark with a $3 \times 10^{-7} \mathrm{M} 4^{\prime}, 6$ diamidino-2-phenylindole (DAPI, Molecular Probes) solution for staining cell nuclei. After rinsing the wells three times with PBS, the chambers were removed. A mounting solution of $50 \%$ glycerol and $50 \%$ PBS was used. Images were examined by using a $40 \times$ objective on a Zeiss Axioplan II fluorescence microscope (Oberkochen, Germany) equipped with monochrome Axiocam and AxioVision 3.1 software. 


\subsection{Results and Discussion}

a

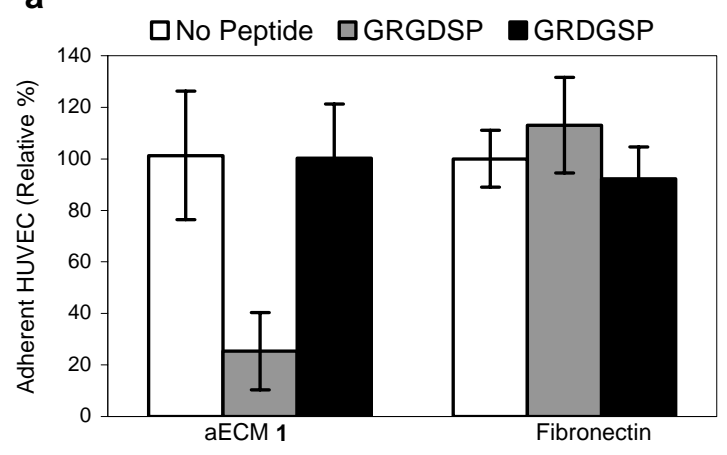

c

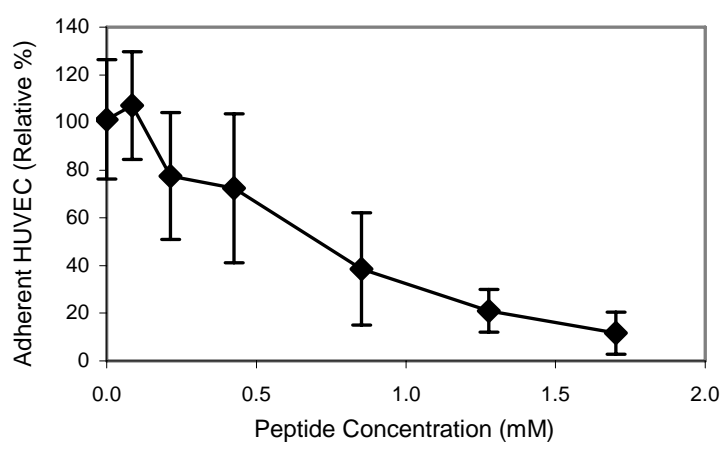

b

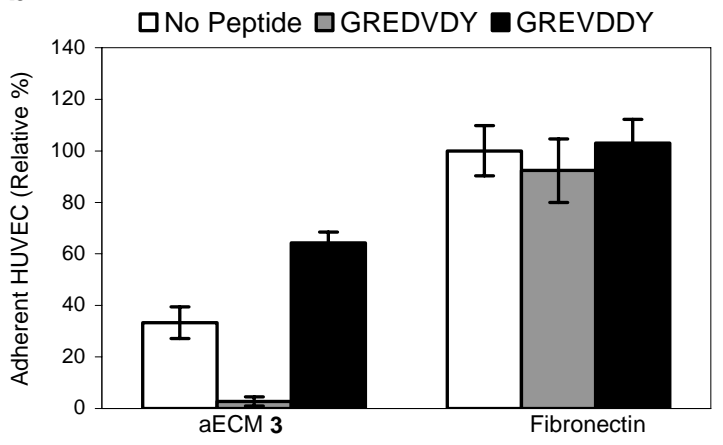

Figure 3.2 Competitive peptide inhibition. (a) Percentage of adherent HUVECs on aECM 1 and fibronectin relative to fibronectin in the absence of peptide. The competitive peptide, GRGDSP, and the noncompetitive peptide, GRDGSP, were added at $1.3 \mathrm{mM}$. (b) Percentage of adherent HUVECs on aECM 3 and fibronectin in the presence of $1.8 \mathrm{mM}$ of GREDVDY, the competitive peptide, and GREVDDY, the noncompetitive peptide. Increasing the concentration of competitive peptide GRGDSP from 0 to 1.7 mM decreased HUVEC adhesion on aECM 1. Data represent three experiments, each performed in triplicate; error bars represent one standard deviation. 


\subsubsection{Competitive Peptide Inhibition}

To test the hypothesis that HUVECs adhere to aECM 1 specifically through the RGD cell-binding domain, competitive peptides were used to inhibit adhesion. When HUVECs were incubated on aECM 1 with $1.3 \mathrm{mM}$ of the competitive GRGDSP peptide, the number of adherent cells was reduced 6-fold (Figure 3.2a). The numbers of adherent HUVECs in Figure 3.2a are expressed relative to the number of cells adherent to fibronectin in the absence of peptide to normalize for passage-to-passage variations. Furthermore, increasing the concentration of the competitive peptide GRGDSP from 0 to $1.7 \mathrm{mM}$ decreased the numbers of adherent HUVEC to aECM 1 with a half-inhibition concentration $\left(\mathrm{IC}_{50}\right)$ of $\sim 0.58 \mathrm{mM}$ (Figure 3.2c). The negative control peptide GRDGSP had no significant effect on the number of adherent cells to aECM 1. Neither of the peptides inhibited adhesion to fibronectin. These results demonstrate that HUVECs adhere specifically to the RGD cell-binding domain in aECM 1 and that this binding can be disrupted in a concentration-dependent manner by a competitive peptide presenting the same cell-binding domain.

In the absence of peptide, the number of adherent HUVECs on aECM 3 was 33.3 $\pm 6.1 \%$ of that on fibronectin. Incubating HUVECs with $1.8 \mathrm{mM}$ of the competitive GREDVDY peptide decreased the number of adherent HUVECs approximately 10-fold (Figure 3.2b). The noncompetitive peptide GREVDDY did not decrease cell adhesion to aECM 3, and neither GREDVDY nor GREVDDY inhibited adhesion to fibronectin. These results show that HUVECs adhere to aECM 3 in a sequence-specific manner and that cell adhesion can be inhibited by soluble peptides that contain the authentic REDV sequence. 

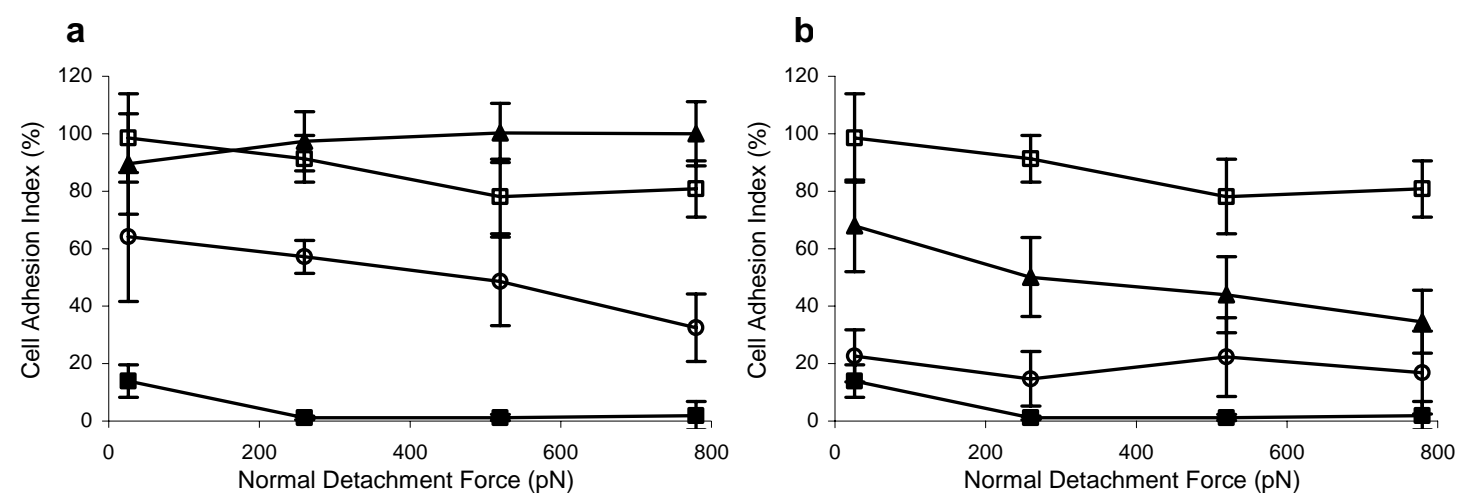

Figure 3.3 HUVEC resistance to detachment forces. (a) Percentages of cells that remain adherent to $\operatorname{aECM} 1(\boldsymbol{\Delta}), \operatorname{aECM} 2(\circ)$, fibronectin $(\square)$, and BSA (घ) after being subjected to detachment forces. (b) Percentages of cells that remain adherent to $\operatorname{aECM} 3(\boldsymbol{\Delta}), \operatorname{aECM} 4(\circ)$, fibronectin $(\square)$, and $\operatorname{BSA}(\mathbf{\square})$ after being subjected to normal detachment forces. Data represent three independent experiments in which six wells were tested; error bars represent one standard deviation.

\subsubsection{HUVEC Resistance to Detachment Forces}

To probe further the specificity of HUVEC adhesion, comparisons were made between aECM proteins $\mathbf{1}$ and 3, and the corresponding negative control proteins that contain scrambled cell-binding domains. After HUVECs were incubated for $30 \mathrm{~min}$ on each test substrate, they were subjected to a normal detachment force for $10 \mathrm{~min}$. The remaining HUVECs were quantified in terms of a cell adhesion index (CAI) as described in the Materials and Methods section. At a detachment force of $780 \mathrm{pN}$, HUVECs on aECM 1 had a CAI of $100 \pm 11.2 \%$ while those on aECM 2 had a CAI of $32.5 \pm 11.8 \%$ (Figure 3.3a). The same detachment force resulted in a CAI of $34.6 \pm 11.0 \%$ on aECM 3 and a CAI of $16.9 \pm 14.4 \%$ on aECM 4 (Figure 3.3b). In each case, adhesion to the 
protein bearing the authentic cell adhesion ligand is more robust than attachment to the negative control protein containing the sequence-scrambled ligand.

Furthermore, under all of the conditions examined in this work (i.e., for detachment forces ranging from 26 to $780 \mathrm{pN}$ ), a larger number of HUVECs remained adherent to aECM 1 than to aECM 3 (Figure 3.3). Because aECM 1 and 3 present similar numbers of cell-binding domains and do not differentially affect cell viability, we believe that this result reflects a difference in the robustness of adhesion mediated by RGD as compared to that mediated by CS5.

\subsubsection{Time Course of HUVEC Spreading}

Cell spreading on aECM substrates was examined at 15 min intervals by phase contrast microscopy. Images were analyzed (as described in the Materials and Methods section) to distinguish between dark, spread cells and bright, rounded cells. After $15 \mathrm{~min}$, $57.0 \pm 2.7 \%$ of HUVECs were spread on aECM 1 while no cells were spread on aECM 2 (Figure 3.4a). These differences persisted after 60 minutes of adhesion (data not shown). After 75 minutes, $18.2 \pm 10.3 \%$ of HUVECs were well-spread on aECM 3 while only 3.8 $\pm 5.0 \%$ were well-spread on aECM 4 (Figure $3.4 \mathrm{~b}$ ). Nearly all of the HUVECs were well-spread on fibronectin at all time points tested while fewer than $1 \%$ of cells spread on BSA at all time points (data not shown).

After 60 min of adhesion, essentially all the HUVECs were well-spread on aECM $1(92.3 \pm 1.5 \%)$, whereas very few had spread on aECM $3(7.3 \pm 3.7 \%)$. These results indicate that HUVECs spread more rapidly on proteins containing the RGD cell-binding domain and do not spread well at short times on proteins containing the CS5 cell- 
a

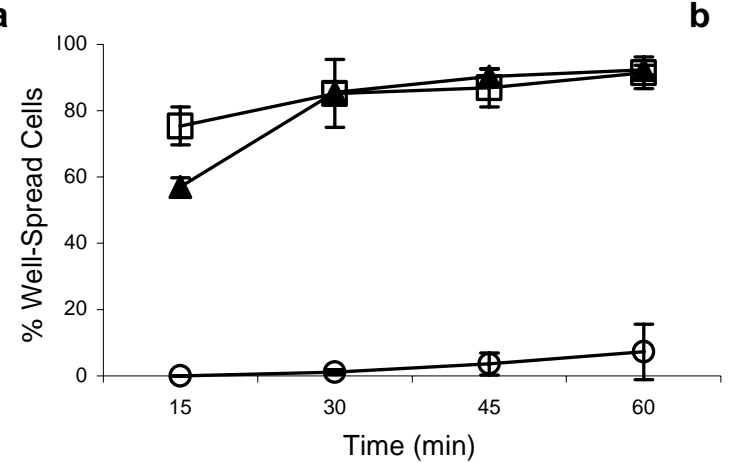

aECM 1

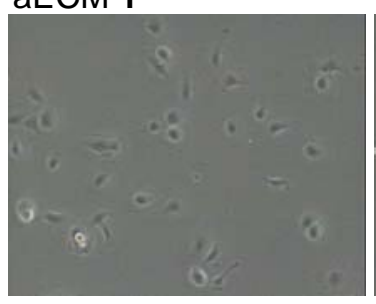

aECM 2

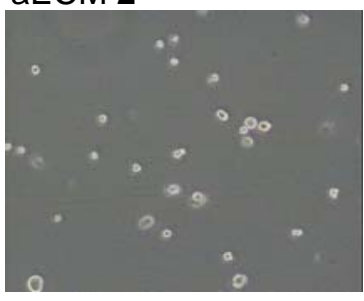

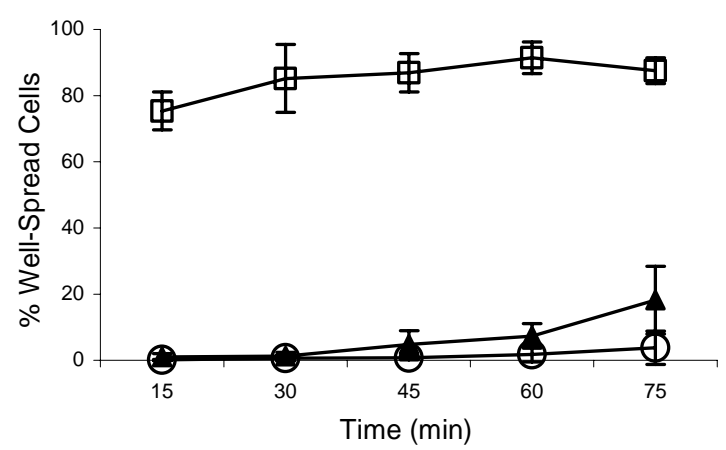

aECM 3

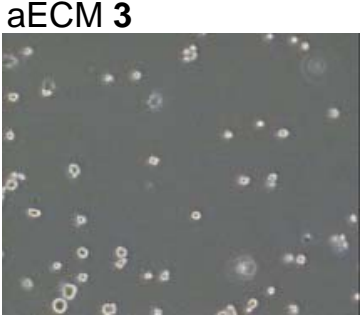

aECM 4

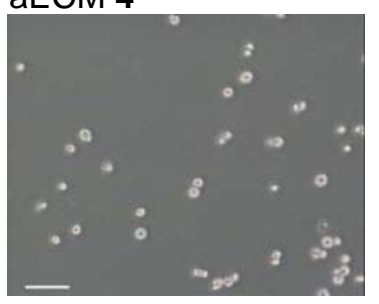

Figure 3.4 Cell spreading on aECM substrates. (a) Percentage of well-spread cells on aECM 1 ( $\mathbf{\Delta})$, aECM $2(\circ)$, and fibronectin ( $\square$ ) from 15 to $60 \mathrm{~min}$ after seeding. The phase contrast images show dark, well-spread cells on aECM 1 and bright, rounded cells on aECM 2 after 60 min of incubation. (b) Percentage of well-spread cells on aECM $3(\mathbf{\Delta}), \operatorname{aECM} 4$ (०), and fibronectin (口). The phase contrast images show that HUVECs are not well-spread on either aECM 3 or aECM 4 after 60 min. Fewer than $1 \%$ of the cells on BSA were well-spread. The phase contrast images were analyzed using Scion Image to determine the number of spread (i.e., dark) versus non-spread (i.e., bright) cells. Three independent experiments were performed and the error bars represent one standard deviation. The scale bar represents $100 \mu \mathrm{m}$. 
binding domain. If HUVECs adhere to the CS5 cell-binding domain through the $\alpha_{4} \beta_{1}$ integrin as has been previously reported ${ }^{54}$ the results shown in Figure 3.4 are consistent with previous studies showing that the $\alpha_{4}$ cytoplasmic tail reduces cell spreading. K562 erythroleukemic cells containing chimeric forms of the $\alpha_{4}$ integrin subunit in which $\alpha_{4}$ extracellular and transmembrane domains were joined to $\alpha_{2}$ and $\alpha_{5}$ cytoplasmic tails spread more rapidly than cells containing the wild-type $\alpha_{4}$ integrin subunit. ${ }^{55}$ Furthermore, when the $\alpha_{4}$ cytoplasmic tail was joined to the $\alpha_{\mathrm{IIb}}$ extracellular and transmembrane domains, $\alpha_{\mathrm{II}} \beta_{3}$-dependent cell spreading of $\mathrm{CHO}$ cells was reduced. ${ }^{56}$

\subsubsection{Visualization of Focal Adhesions and Integrin Clusters}

Since HUVECs spread well on aECM 1, spreading on this substrate was investigated more thoroughly by labeling cells for F-actin and vinculin, a protein found at focal adhesions. Figure 3.5 shows cells on aECM 1 with long, well-formed stress fibers and focal adhesions localized at the ends of these fibers. Similarly, cells on fibronectin had well-formed actin networks with vinculin localized in clusters at the ends of these filaments. Cells on BSA were small and rounded, whereas cells on aECM 2 did not have well-formed actin networks (data not shown). Vinculin was nonspecifically distributed throughout the cells when cells were examined on BSA or aECM 2. These results further support the observation that cells are well-spread on aECM proteins bearing the RGD cell-binding domain and indicate that HUVECs form distinct focal adhesions when adhering to aECM 1. 


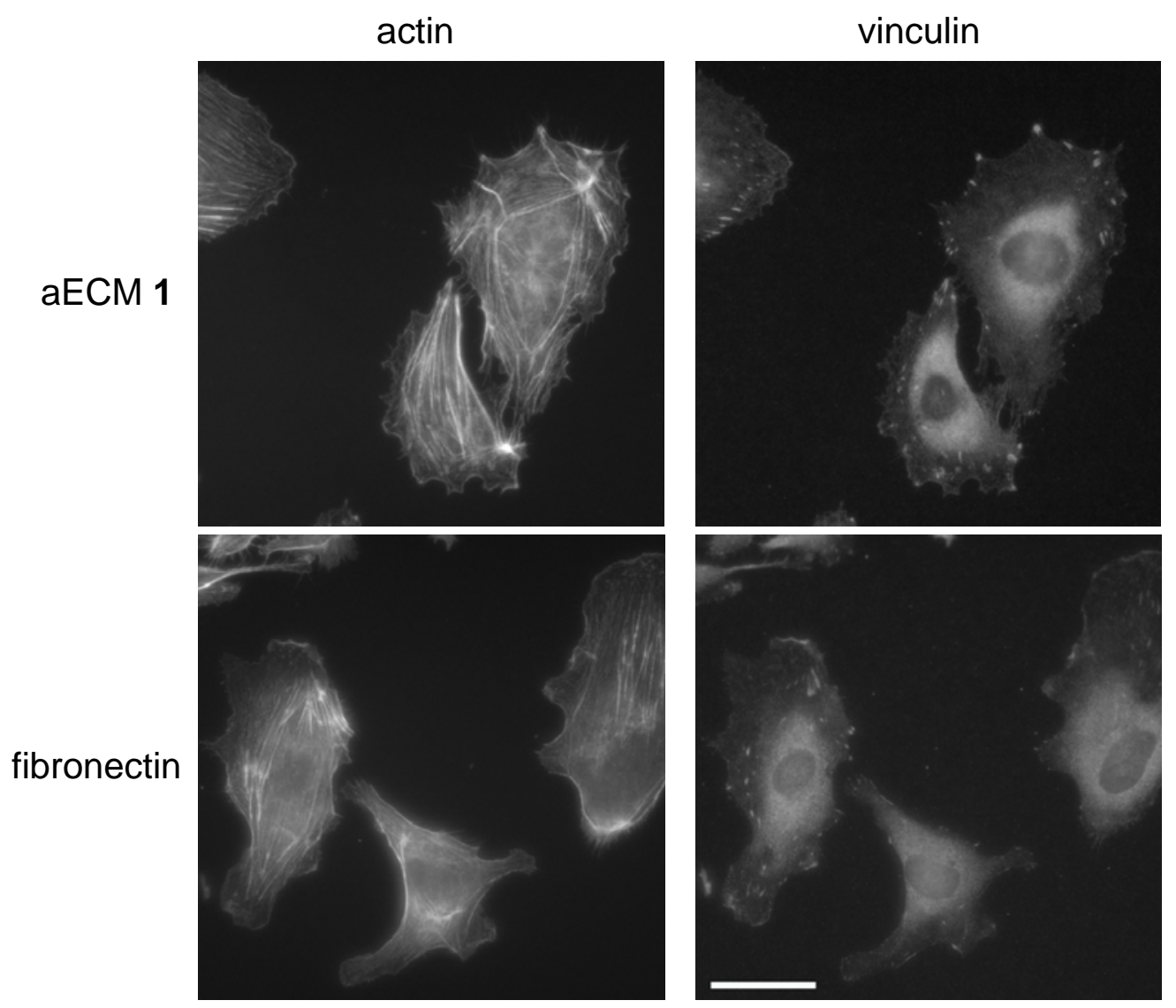

Figure 3.5 Fluorescence micrographs of actin filaments and focal adhesions in HUVECs. Cells incubated on aECM 1 or fibronectin for $4 \mathrm{~h}$ were labeled with rhodamine-phalloidin and an anti-vinculin $\operatorname{IgG}_{1}$ antibody and detected with a Cy2-conjugated secondary antibody. The scale bar represents $25 \mu \mathrm{m}$.

To investigate the mechanism by which HUVECs bind to and spread on aECM 1, immunofluorescence microscopy was used to visualize the $\alpha_{v} \beta_{3}$ and $\alpha_{5} \beta_{1}$ integrins. When HUVECs adhered to aECM 1 , the $\alpha_{v} \beta_{3}$ integrin was localized in small clusters found at the ends of actin filaments (Figure 3.6a), whereas the $\alpha_{5} \beta_{1}$ integrin was found nonspecifically throughout the cell (Figure 3.6b). This result suggests that the $\alpha_{\mathrm{v}} \beta_{3}$ 
integrin is found in focal adhesions and that it is involved in HUVEC adhesion to the RGD cell-binding domain in aECM 1. In HUVECs attached to fibronectin, the $\alpha_{v} \beta_{3}$ integrin was found nonspecifically throughout the cell (Figure 3.6a), whereas the $\alpha_{5} \beta_{1}$ integrin was found throughout the cell in large structures corresponding to the ends of actin filaments (Figure 3.6b). This result shows that the $\alpha_{5} \beta_{1}$ integrin is found in focal adhesions when cells adhere to fibronectin and suggests that HUVECs bind to this substrate through the $\alpha_{5} \beta_{1}$ integrin. The finding that HUVECs bind to aECM 1 through the $\alpha_{v} \beta_{3}$ integrin and to fibronectin through the $\alpha_{5} \beta_{1}$ integrin is not surprising given that the $\alpha_{5} \beta_{1}$ integrin binds to the RGD cell-binding domain in conjunction with the PHSRN synergy site found in fibronectin, ${ }^{57,58}$ whereas the $\alpha_{v} \beta_{3}$ integrin has been found to be less stringent in its requirements and binds a variety of proteins with the RGD sequence, including vitronectin, ${ }^{44}$ fibronectin, ${ }^{59}$ fibrinogen, von Willebrand factor, ${ }^{60}$ and thrombospondin. ${ }^{61}$

Figure 3.6 (on next page) Fluorescence micrographs of actin filaments and integrins. (a) Cells cultured for $4 \mathrm{~h}$ on aECM 1 or on fibronectin were labeled with rhodamine-phalloidin and an anti- $\alpha_{\mathrm{v}} \beta_{3} \quad \mathrm{IgG}_{1}$ antibody and detected with a Cy2-conjugated secondary antibody. (b) Cells cultured for $4 \mathrm{~h}$ on aECM 1 or on fibronectin were labeled with rhodamine-phalloidin and an anti- $\alpha_{5} \beta_{1}$ IgG antibody and detected with a Cy2-conjugated secondary antibody. The scale bar represents $25 \mu \mathrm{m}$. 


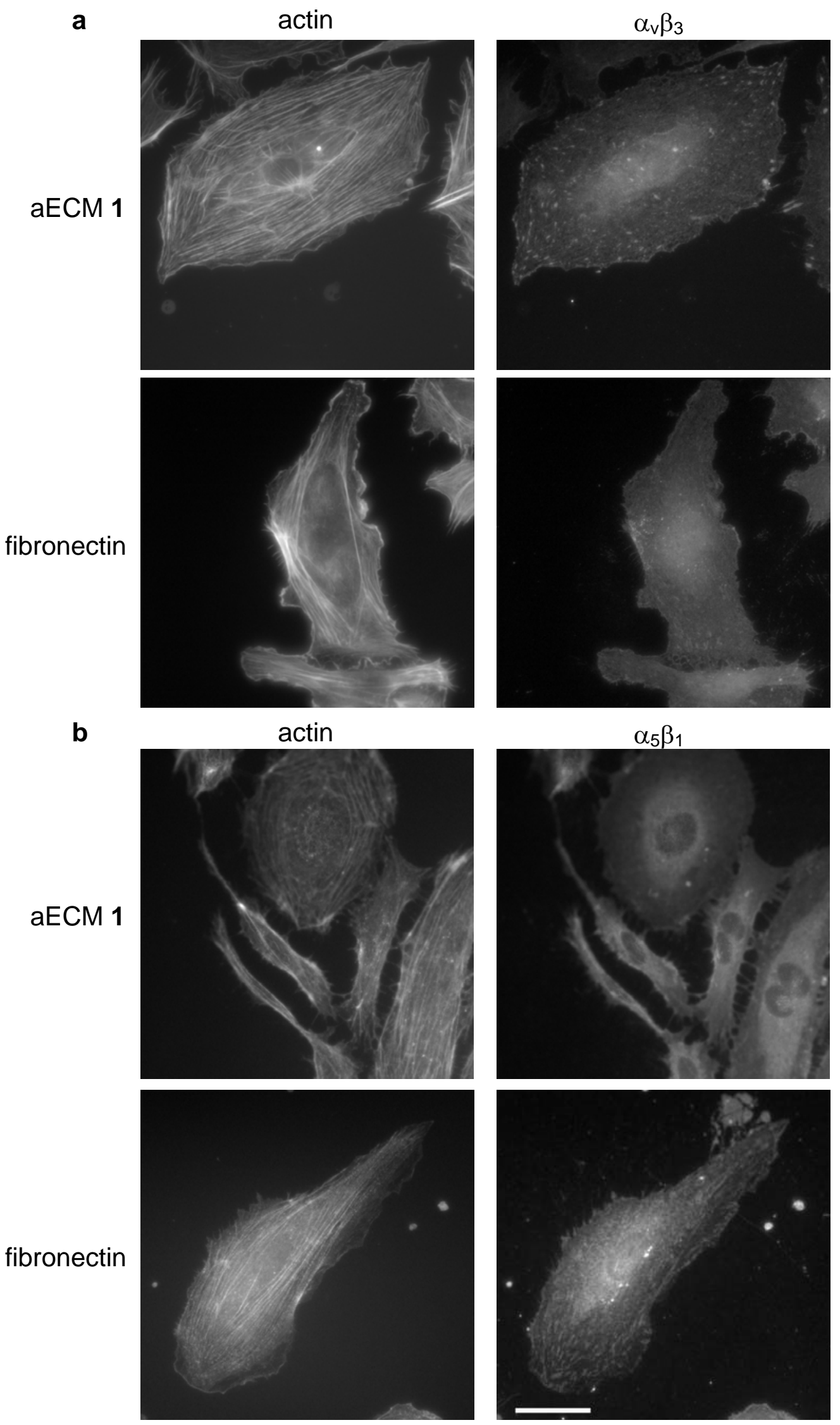




\subsection{Conclusion}

Sequence-specific cell adhesion to aECM proteins containing the RGD and CS5 cell-binding domains has been demonstrated. In the context of the same aECM protein backbone, the RGD cell-binding domain binds endothelial cells more strongly and elicits faster cell spreading than the CS5 cell-binding domain. Cell response to the aECM proteins can thus be altered by judicious choice of cell-binding domains. Further studies will determine the degree to which endothelial cell responses can be modulated by mixing cell-binding domains.

In addition to varying the cell response through the cell-binding domain, it has been previously shown that the mechanical properties of crosslinked, free-standing films

can be controlled through factors such as the extent of crosslinking. ${ }^{10,11,13}$ The ability to control both cell response and mechanical properties in a single material is highly desirable in a vascular graft. Current and future studies will examine cell responses to crosslinked, free-standing aECM films and continue to assess the suitability of aECM proteins for use in vascular implants.

\subsection{Acknowledgments}

We thank Kathleen Di Zio for helpful discussions regarding the DNA cloning and protein purification, Anand Asthagiri for helpful discussions regarding the cell spreading studies, and Scott Fraser and Carole Lu for help with the fluorescence microscopy. This work was supported by NIH Grant 5 RO1 HL59987-03, NSF Grant BES-9901648, and a Whitaker graduate fellowship. 


\subsection{References}

1. American Heart Association, Heart Disease and Stroke Statistics-2003 Update. American Heart Association: Dallas, TX, 2002.

2. Rayner M, Petersen S, European Cardiovascular Disease Statistics. British Heart Foundation: London, 2000.

3. Nugent HM, Edelman ER. Tissue engineering therapy for cardiovascular disease. Circ.Res. 2003, 92, 1068-1078.

4. Salacinski HJ, Tiwari A, Hamilton G, Seifalian AM. Cellular engineering of vascular bypass grafts: Role of chemical coatings for enhancing endothelial cell attachments. Med. Biol. Eng. Comput. 2001, 39, 609-618.

5. Bos GW, Poot AA, Beugeling T, van Aken WG, Feijen J. Small-diameter vascular graft prostheses: Current status. Arch. Physiol. Biochem. 1998, 106, 100115.

6. Veith FJ et al. Six-year prospective multicenter randomized comparison of autologous saphenous vein and expanded polytetrafluoroethylene grafts in infrainguinal arterial reconstructions. J. Vasc. Surg. 1986, 3, 104-114.

7. Bergan JJ, Veith FJ, Bernhard VM, Yao JST, Flinn WR, Gupta SK, Scher LA, Samson RH, Towne JB. Randomization of autogenous vein and polytetrafluoroethylene grafts in femoral-distal reconstruction. Surgery 1982, 92, 921-930.

8. Ratcliffe A. Tissue engineering of vascular grafts. Matrix Biol. 2000, 19, 353357.

9. Panitch A, Yamaoka T, Fournier MJ, Mason TL, Tirrell DA. Design and biosynthesis of elastin-like artificial extracellular matrix proteins containing periodically spaced fibronectin CS5 domains. Macromolecules 1999, 32, 17011703.

10. Welsh ER, Tirrell DA. Engineering the extracellular matrix: A novel approach to polymeric biomaterials. I. Control of the physical properties of artificial protein 
matrices designed to support adhesion of vascular endothelial cells.

Biomacromolecules 2000, 1, 23-30.

11. Di Zio K, Tirrell DA. Mechanical properties of artificial protein matrices engineered for control of cell and tissue behavior. Macromolecules 2003, 36, 1553-1558.

12. Heilshorn SC, Di Zio K, Welsh ER, Tirrell DA. Endothelial cell adhesion to the fibronectin CS5 domain in artificial extracellular matrix proteins. Biomaterials 2003, 24, 4245-4252.

13. Nowatzki PJ, Tirrell DA. Physical properties of artificial extracellular matrix protein films prepared by isocyanate crosslinking. Biomaterials 2004, 25, 12611267.

14. Hong M, Isailovic D, McMillan RA, Conticello VP. Structure of an elastinmimetic polypeptide by solid-state NMR chemical shift analysis. Biopolymers 2003, 70, 158-168.

15. Trabbic-Carlson K, Setton LA, Chilkoti A. Swelling and mechanical behaviors of chemically cross-linked hydrogels of elastin-like polypeptides.

Biomacromolecules 2003, 4, 572-580.

16. Urry DW, Pattanaik A, Xu J, Woods TC, McPherson DT, Parker TM. Elastic protein-based polymers in soft tissue augmentation and generation. J. Biomater. Sci.-Polym. Ed. 1998, 9, 1015-1048.

17. Halstenberg S, Panitch A, Rizzi S, Hall H, Hubbell JA. Biologically engineered protein-graft-poly(ethylene glycol) hydrogels: A cell adhesive and plasmindegradable biosynthetic material for tissue repair. Biomacromolecules 2002, 3, $710-723$.

18. Urry DW. Physical chemistry of biological free energy transduction as demonstrated by elastic protein-based polymers. J. Phys. Chem. B 1997, 101, 11007-11028. 
19. Urry DW, Gowda DC, Parker TM, Luan CH, Reid MC, Harris CM, Pattanaik A, Harris RD. Hydrophobicity scale for proteins based on inverse temperature transitions. Biopolymers 1992, 32, 1243-1250.

20. Urry DW, Parker TM, Reid MC, Gowda DC. Biocompatibility of the bioelastic materials, poly(GVGVP) and its $\gamma$-irradiation cross-linked matrix: Summary of generic biological test results. J. Bioact. Compat. Polym. 1991, 6, $263-282$.

21. Nicol A, Gowda DC, Urry DW. Cell adhesion and growth on synthetic elastomeric matrices containing Arg-Gly-Asp-Ser- ${ }^{3}$. J. Biomed. Mater. Res. 1992, 26, 393-413.

22. Salacinski HJ, Goldner S, Giudiceandrea A, Hamilton G, Seifalian AM, Edwards A, Carson RJ. The mechanical behavior of vascular grafts: A review. J. Biomater. Appl. 2001, 15, 241-278.

23. Greenwald SE, Berry CL. Improving vascular grafts: The importance of mechanical and haemodynamic properties. J. Pathol. 2000, 190, 292-299.

24. Crawshaw HM, Quist WC, Serrallach E, Valeri CR, Logerfo FW. Flow disturbance at the distal end-to-side anastomosis-Effect of patency of the proximal outflow segment and angle of anastomosis. Arch. Surg. 1980, 115, $1280-1284$.

25. Logerfo FW, Soncrant T, Teel T, Dewey CF. Boundary layer separation in models of side-to-end arterial anastomoses. Arch. Surg. 1979, 114, 1369-1373.

26. Brossollet LJ. Mechanical issues in vascular grafting-A review. Int. J. Artif. Organs 1992, 15, 579-584.

27. Seifalian AM, Salacinski HJ, Tiwari A, Edwards A, Bowald S, Hamilton G. In vivo biostability of a poly(carbonate-urea)urethane graft. Biomaterials 2003, 24 , 2549-2557.

28. Glickman MH, Stokes GK, Ross JR, Schuman ED, Sternbergh WC, Lindberg JS, Money SM, Lorber MI. Multicenter evaluation of a polyurethaneurea vascular 
access graft as compared with the expanded polytetrafluoroethylene vascular access graft in hemodialysis applications. J. Vasc. Surg. 2001, 34, 465-472.

29. Akiyama N, Esato K, Fujioka K, Zempo N. A comparison of CORVITA and expanded polytetrafluoroethylene vascular grafts implanted in the abdominal aortas of dogs. Surg. Today-Jpn. J. Surg. 1997, 27, 840-845.

30. Ross MH, Romrell LJ, Gordon IK, Histology: A Text and Atlas. Williams \& Wilkins: Baltimore, MD, 1995.

31. Fung YC, Biomechanics: Mechanical Properties of Living Tissues. SpringerVerlag: New York, NY, 1993.

32. Greisler H, New Biologic and Synthetic Vascular Prostheses. R.G. Landes Company: Austin, TX, 1991.

33. Gross PL, Aird WC. The endothelium and thrombosis. Semin. Thromb. Hemost. 2000, 26, 463-478.

34. Sagripanti A, Carpi A. Antithrombotic and prothrombotic activities of the vascular endothelium. Biomed. Pharmacother. 2000, 54, 107-111.

35. Deutsch M, Meinhart J, Fischlein T, Preiss P, Zilla P. Clinical autologous in vitro endothelialization of infrainguinal ePTFE grafts in 100 patients: A 9-year experience. Surgery 1999, 126, 847-855.

36. Gherardini G, Haegerstrand A, Matarasso A, Gurlek A, Evans GRD, Lundeberg T. Cell adhesion and short-term patency in human endothelium preseeded 1.5-mm polytetrafluoroethylene vascular grafts: An experimental study. Plast. Reconstr. Surg. 1997, 99, 472-478.

37. Walluscheck KP, Steinhoff G, Kelm S, Haverich A. Improved endothelial cell attachment on ePTFE vascular grafts pretreated with synthetic RGD-containing peptides. Eur. J. Vasc. Endovasc. Surg. 1996, 12, 321-330.

38. Sank A, Rostami K, Weaver F, Ertl D, Yellin A, Nimni M, Tuan TL. New evidence and new hope concerning endothelial seeding of vascular grafts. Am. J. Surg. 1992, 164, 199-204. 
39. Stansby G, Berwanger C, Shukla N, Schmitzrixen T, Hamilton G. Endothelial seeding of compliant polyurethane vascular graft material. Br. J. Surg. 1994, 81, 1286-1289.

40. Ozaki CK, Phaneuf MD, Hong SL, Quist WC, Logerfo FW. Glycoconjugate mediated endothelial cell adhesion to Dacron polyester film. J. Vasc. Surg. 1993, $18,486-494$.

41. Pierschbacher M, Hayman EG, Ruoslahti E. Synthetic peptide with cell attachment activity of fibronectin. Proc. Natl. Acad. Sci. U. S. A. 1983, 80, 12241227.

42. Pierschbacher MD, Ruoslahti E. Variants of the cell recognition site of fibronectin that retain attachment-promoting activity. Proc. Natl. Acad. Sci. U. S. A. 1984, 81, 5985-5988.

43. Pierschbacher MD, Ruoslahti E. Cell attachment activity of fibronectin can be duplicated by small synthetic fragments of the molecule. Nature 1984, 309, 3033.

44. Pytela R, Pierschbacher MD, Ruoslahti E. A 125/115-kDa cell surface receptor specific for vitronectin interacts with the arginine-glycine-aspartic acid adhesion sequence derived from fibronectin. Proc. Natl. Acad. Sci. U. S. A. 1985, 82, 5766-5770.

45. Pytela R, Pierschbacher MD, Ruoslahti E. Identification and isolation of a $140 \mathrm{kd}$ cell surface glycoprotein with properties expected of a fibronectin receptor. Cell 1985, 40, 191-198.

46. Humphries MJ, Akiyama SK, Komoriya A, Olden K, Yamada KM. Identification of an alternatively spliced site in human plasma fibronectin that mediates cell type-specific adhesion. J. Cell Biol. 1986, 103, 2637-2647.

47. Humphries MJ, Komoriya A, Akiyama SK, Olden K, Yamada KM. Identification of two distinct regions of the type III connecting segment of human plasma fibronectin that promote cell type-specific adhesion. J. Biol. Chem. 1987, 262, 6886-6892. 
48. Mould AP, Komoriya A, Yamada KM, Humphries MJ. The CS5 peptide is a second site in the IIICS region of fibronectin recognized by the integrin $\alpha_{4} \beta_{1}$. J. Biol. Chem. 1991, 266, 3579-3585.

49. Hubbell JA, Massia SP, Desai NP, Drumheller PD. Endothelial cell-selective materials for tissue engineering in the vascular graft via a new receptor. BioTechnology 1991, 9, 568-572.

50. Ausubel FM, Brent R, Kingston RE, Moore DD, Seidman JG, Smith JA, Struhl K (eds.), Current Protocols in Molecular Biology. John Wiley \& Sons, Inc.: New York, NY, 2003.

51. Sambrook J, Frisch EF, Maniatis T, Molecular Cloning. Cold Spring Harbor Laboratory Press: Plainview, NY, 1989.

52. Channavajjala LS, Eidsath A, Saxinger WC. A simple method for measurement of cell-substrate attachment forces: Application to HIV-1 Tat. J. Cell Sci. 1997, 110, 249-256.

53. Koo LY, Irvine DJ, Mayes AM, Lauffenburger DA, Griffith LG. Co-regulation of cell adhesion by nanoscale RGD organization and mechanical stimulus. J. Cell Sci. 2002, 115, 1423-1433.

54. Massia SP, Hubbell JA. Vascular endothelial cell adhesion and spreading promoted by the peptide REDV of the IIICS region of plasma fibronectin is mediated by integrin $\alpha_{4} \beta_{1}$. J. Biol. Chem. 1992, 267, 14019-14026.

55. Kassner PD, Alon R, Springer TA, Hemler ME. Specialized functional properties of the integrin $\alpha^{4}$ cytoplasmic domain. Mol. Biol. Cell 1995, 6, 661-674.

56. Liu S, Thomas SM, Woodside DG, Rose DM, Kiosses WB, Pfaff M, Ginsberg $\mathrm{MH}$. Binding of paxillin to $\alpha_{4}$ integrins modifies integrin-dependent biological responses. Nature 1999, 402, 676-681.

57. Aota S, Nomizu M, Yamada KM. The short amino acid sequence Pro-His-SerArg-Asn in human fibronectin enhances cell-adhesive function. J. Biol. Chem. 1994, 269, 24756-24761. 
58. Danen EHJ, Aota SI, Vankraats AA, Yamada KM, Ruiter DJ, Vanmuijen GNP. Requirement for the synergy site for cell adhesion to fibronectin depends on the activation state of integrin $\alpha_{5} \beta_{1}$. J. Biol. Chem. 1995, 270, 21612-21618.

59. Cheresh DA. Human endothelial cells synthesize and express an Arg-Gly-Aspdirected adhesion receptor involved in attachment to fibrinogen and von Willebrand factor. Proc. Natl. Acad. Sci. U. S. A. 1987, 84, 6471-6475.

60. Charo IF, Nannizzi L, Smith JW, Cheresh DA. The vitronectin receptor $\alpha_{\mathrm{v}} \beta_{3}$ binds fibronectin and acts in concert with $\alpha_{5} \beta_{1}$ in promoting cellular attachment and spreading on fibronectin. J. Cell Biol. 1990, 111, 2795-2800.

61. Lawler J, Weinstein R, Hynes RO. Cell attachment to thrombospondin: The role of Arg-Gly-Asp, calcium, and integrin receptors. J. Cell Biol. 1988, 107, 23512361. 